\title{
Avatrombopag Maleate
}

National Cancer Institute

\section{Source}

National Cancer Institute. Avatrombopag Maleate. NCI Thesaurus. Code C142941.

The maleate salt form of avatrombopag, an orally available platelet thrombopoietin receptor (TPOR; MPL) agonist, with potential megakaryopoiesis stimulating activity. Upon administration, avatrombopag binds to and stimulates TPOR, which may lead to the proliferation and differentiation of megakaryocytes from bone marrow progenitor cells. This increases the production of platelets and may prevent chemotherapy-induced thrombocytopenia (CIT). TPOR is a cytokine receptor and member of the hematopoietin receptor superfamily. 